Jurnal Ekonomi Syariah Teori dan Terapan p-ISSN: 2407-1935, e-ISSN: 2502-1508. Vol. 7 No. 5 Mei 2020: 886-900; DOI: 10.20473/vol7iss20205pp886-900

THE EFFECT OF FINANCIAL AND NON-FINANCIAL VARIABLES ON STOCK UNDERPRICING IN THE SERVICE COMPANIES WHEN INITIAL PUBLIC OFFERING (IPO) IN INDONESIA STOCK EXCHANGE (BEI): A CASE STUDY IN SHARIAH AND NON-SHARIAH STOCKS FOR 2012-2017 PERIOD1

\title{
PENGARUH VARIABEL KEUANGAN DAN NON-KEUANGAN TERHADAP UNDERPRICING SAHAM PADA PERUSAHAAN JASA SAAT INITIAL PUBLIC OFFERING (IPO) DI BURSA EFEK INDONESIA (BEI): STUDI KASUS PADA SAHAM SYARIAH DAN NON SYARIAH PERIODE 2012-2017
}

\author{
Vabila Ananta Setya, Bayu Arie Fianto \\ Departemen Ekonomi Syariah - Fakultas Ekonomi dan Bisnis - Universitas Airlangga \\ vabilaananta@gmail.com*, bayu.fianto@feb.unair.ac.id
}

\begin{abstract}
ABSTRAK
Penelitian ini bertujuan untuk menyelidiki faktor-faktor yang mempengaruhi underpricing saham di perusahaan jasa selama penawaran umum perdana (IPO) di Bursa Efek Indonesia (BEI) untuk periode 2012-2017 (Perbandingan saham Syariah dan nonsyariah). Data yang digunakan dalam penelitian ini terdiri dari 20 saham yang mengalami underpricing dari total 44 IPO perusahaan jasa yang sesuai syariah dan 19 saham yang mengalami underpricing dari total 32 IPO perusahaan jasa yang tidak sesuai syariah. Pendekatan penelitian yang digunakan adalah pendekatan kuantitatif dengan teknik analisis regresi linier berganda. Penelitian ini mengungkapkan bahwa reputasi penjamin emisi dan reputasi auditor memiliki pengaruh yang signifikan terhadap underpricing pada IPO di Bursa Efek Indonesia (BEI) untuk periode 2012-2017.
\end{abstract}

Kata kunci: underpricing, reputasi penjamin emisi, reputasi auditor, leverage keuangan, Return on Asset, Initial Public Offering (IPO)

\begin{abstract}
This study aims to investigate the factors that influence the underpricing of stocks in service companies during an initial public offering (IPO) on Bursa Efek Indonesia (BEI) for the period 20122017 (Comparison of Sharia and non-sharia stocks). The data used in this study consist of 20 stocks that experienced the underpricing from a total of 44 IPOs of sharia-compliant service companies and 19 stocks that experienced the underpricing from a total of 32 IPOs of non-shariah-compliant service companies. The research approach used is a quantitative approach with multiple linear regression analysis techniques. This research reveals that the underwriter reputation and auditor reputation have a significant effect on the underpricing at the IPO on Bursa Efek Indonesia (BEI) for the period 2012-2017.

Keyword: Underpricing, Underwriter Reputation, Auditor Reputation, Financial Leverage, Return on Assets, Initial Public Offering (IPO)
\end{abstract}

Informasi artikel

Diterima: 05-03-2020

Direview: 20-04-2020

Diterbitkan: 18-05-2020

${ }^{*}$ Korespondensi

(Correspondence):

Vabila Ananta Setya

Open access under Creative Commons Attribution-Non Commercial-Share A like 4.0 International Licence (CC-BY-NC-SA) (c) () (-)

\footnotetext{
${ }^{1}$ Artikel ini merupakan bagian dari skripsi dari Vabila Ananta Setya, NIM: 041411433044, yang berjudul, "Faktor-faktor yang Mempengaruhi Underpricing Saham pada Perusahaan SASA Saat Initial Public Offering (IPO) di Bursa Efek Indonesia (Studi kasus pada saham syariah-non syariah) Periode 2011-2017."
} 


\section{PENDAHULUAN}

Berinvestasi pada instrumen kevangan atau financial assets menjadi sebuah cara yang banyak digemari oleh para pemilik saham beberapa periode terakhir (R. Nugroho dan Nanda, 2016). Hal ini menunjukkan masyarakat semakin paham akan pengelolaan keuangan dan investasi. Saat ini, banyak masyarakat memilih untuk berinvestasi pada produk investasi di pasar modal yang dianggap ideal karena tingkat keuntungan yang ditawarkan relatif cukup tinggi (Nugroho dan Nanda 2016)

Dalam kevangan syariah terdapat dua kaidah figh yang terkait dengan risiko, yakni al kharaj bi al dhaman dan al ghummu bi al ghurm. Kedua kaidah figh ini memiliki arti bahwa setiap return yang didapatkan dari asset, secara intrinsik terkait dengan tanggung jawab atas kerugian yang muncul dari asset tersebut. Jadi dalam dunia keuangan syariah dari asset yang didapatkan pasti adanya risiko dan pihak yang terkait siap menanggung apabila adanya kerugian (Khan \& Ahmed, 2008).

Menurut Siamat (2005), pasar modal dalam arti sempit adalah suatu tempat yang terorganisasi di mana efekefek diperdagangkan yang disebut Bursa Efek. Bursa efek atau stock exchange adalah suatu sistem yang terorganisasi yang mempertemukan penjual dan pembeli efek yang dilakukan baik secara langsung maupun melalui wakil-wakilnya. Fungsi Bursa Efek ini antara lain adalah menjaga kontinuitas pasar dan menciptakan harga efek yang wajar melalui mekanisme permintaan dan penawaran.

Pasar modal syariah di Indonesia diatur oleh Fatwa Dewan Syariah Nasional Majelis Ulama Indonesia (DSN-MUI) Nomor 40/DSN-MUI/X2003. Secara mendasar, pasar modal tidak bertentangan dengan syariah. Pasar modal juga merupakan pasar sebagaimana pasar pada umumnya, yang melibatkan penjualan dan pembelian di dalamnya. Jual-beli dalam syariah merupakan hal yang tidak dilarang.

Pertumbuhan saham syariah dari tahun ketahun terus berkembang secara signifikan seperti pada statistik saham di situs resmi OJK (Otoritas Jasa Keuangan) yang dapat dilihat pada tabel 1.

Tabel 1.

Perkembangan Kapitalisasi Pasar Di BEI (Rp Trilliun)

\begin{tabular}{ccccc}
\multicolumn{5}{c}{$2012-2017$} \\
Tahun & IHSG & LQ45 & JII & ISSI \\
\hline $\mathbf{2 0 1 1}$ & $3,537.29$ & $2,339.18$ & $1,414.98$ & $1,968.09$ \\
$\mathbf{2 0 1 2}$ & $4,126.99$ & $2,559.44$ & $1,671.00$ & $2,451.33$ \\
$\mathbf{2 0 1 3}$ & $4,219.02$ & $2,547.06$ & $1,672.10$ & $2,557.84$ \\
$\mathbf{2 0 1 4}$ & $5,288.04$ & $3,337.43$ & $1,944.53$ & $2,946.89$ \\
$\mathbf{2 0 1 5}$ & $4,872.70$ & $2,953.11$ & $1,737.29$ & $2,600.85$ \\
$\mathbf{2 0 1 6}$ & $5,723.61$ & $3,796.30$ & $2,035.19$ & $3,256.32$ \\
$\mathbf{2 0 1 7}$ & $6,889.49$ & $4,577.57$ & $2,242.12$ & $3,510.10$
\end{tabular}

Sumber: Data Statistik Saham Syariah OJK

Perusahaan-perusahaan yang

beroperasi secara syariah dan mengeluarkan produk-produk syariah kini kian bertambah dan berkembang. Dimana mereka menawarkan saham syariah sehingga nama perusahaan mereka tercatat di dalam Daftar Efek Syariah (Jannah, 2016). Hal tersebut berakibat pada semakin banyaknya 
perusahaan syariah yang melakukan IPO di BEl.

Menurut Anwar (2010), bahwa suatu perusahaan yang berkembang umumnya melakukan ekspansi usaha melalui pengembangan produk maupun usaha baru. Untuk itu, alternatif pembiayaan yang terbaik harus dipilih. Sesuai dengan prinsip keuangan korporasi, salah satu pilihannya adalah go public yakni membagi kepemilikan saham dengan publik dan sebagai kompensasinya perusahaan memperoleh tambahan modal yang diperlukan. Perusahaan yang go public di BEl tergolong menjadi tiga sektor yaitu (Jannah, 2016):

1. Sektor Utama: Sektor Pertanian \& Pertambangan.

2. Sektor Manufaktur: Sekor Industri Dasar dan Bahan Kimia, Aneka Industri \& Industri Barang Konsumsi.

3. Sektor Jasa: Sektor Property Real Estate, Sektor Infrastruktur, Sektor Utility dan Transportasi, Sektor Keuangan \& Sektor Perdagangan, Jasa dan Investasi.

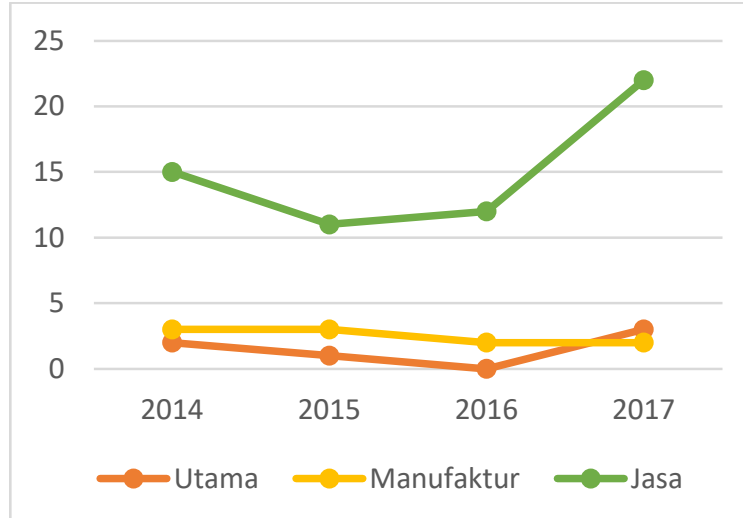

Gambar 1.

Grafik Perkembangan Penawaran Umum Perdana
Dari gambar 1 di atas, dapat dilihat data statistik pasar modal selama empat tahun belakangan dari tahun 20142017, menunjukkan bahwa sektor jasa selalu menempati peringkat pertama terbanyak dari perusahaan yang melakukan penawaran perdana dibandingkan dengan perusahaan pada sektor lainnya. Hal ini menunjukkan perkembangan yang bagus di sektor perusahaan jasa.

Kaitannya dengan go public, setelah sebuah perusahaan memutuskan untuk menjadi perusahaan yang go public, maka harus diawali melalui penawaran saham perdana yang disebut IPO (Initial Public Offering). Handayani (2008) menyatakan bahwa Initial Public Offering (IPO) merupakan kegiatan perusahaan untuk menjual sahamnya kepada publik melalui pasar modal untuk pertama kalinya. Tahapan IPO antara lain menyusun perencanaan, persiapan, mendapatkan pernyataan pendaftaran dari OJK, penawaran umum, seta melaksanakan semua kewajiban sebagai emiten setelah sah dinyatakan go public (Muhamad, 2006).

Kegiatan IPO di dalam suatu perusahaan banyak diwarnai dengan adanya suatu fenomena yang disebut underpricing (Chastina dan Martani, 2005). Underpricing adalah peristiwa ketika harga saham yang ditawarkan di pasar perdana lebih rendah dibandingkan harga saham di pasar sekunder (Safithri, Setyaningsih, Tarman, Suptijah dan Yuhendri, 2018). Fenomena 
ini dapat merugikan perusahaan karena perusahaan tidak mendapatkan dana yang optimal dari IPO. Sedangkan bagi investor, hal ini akan menguntungkan karena investor mendapatkan initial return (keuntungan awal).

Kondisi underpricing akan merugikan perusahaan yang melakukan go public atau biasa disebut perusahaan emiten, karena dana yang diperoleh dari investor tidak maksimum (Retnowati, 2013). Menurut Suyatmi dan Sujadi (2006), Underpricing dapat dianalisis melalui beberapa faktor yaitu variabel keuangan (Ukuran Perusahaan, Return on Investment, Financial leverage, EPS, Return on assets, Proceeds, dan Current Ratio) dan variabel non-kevangan (Umur Perusahaan, Reputasi Underwriter, Reputasi Auditor, dan Jenis Industri). Oleh karena itu perlu diketahui faktor-faktor yang menyebabkan fenomena ini agar underpricing dapat ditekan dan kedepannya nanti tidak merugikan baik dari pihak perusahaan maupun dari pihak investor.

Dalam proses go public, sebelum saham diperdagangkan di pasar sekunder (bursa efek), terlebih dahulu saham perusahaan yang akan go public dijual di pasar perdana (Daljono, 2000). Harga saham pada penawaran perdana ditentukan berdasarkan kesepakatan antara perusahaan emiten dengan underwriter (penjamin emisi efek), sedangkan harga saham di pasar sekunder ditentukan oleh mekanisme pasar (berdasarkan permintaan dan penawaran). Menurut Fahmi (2012), Underwriter adalah "penjamin emisi bagi setiap perusahaan yang akan menerbitkan sahamnya di pasar modal". Tugas pokok dari underwriter adalah untuk menjualkan efek yang diterbitkan perusahaan kepada masyarakat umum.

Selain underwriter faktor reputasi auditor juga harus diperhatikan karena Menurut Kadek, Raditya dan Yasa (2017), reputasi auditor juga berpengaruh negatif terhadap underpricing. Dimana reputasi auditor merupakan salah satu informasi non-keuangan yang terdapat dalam prospectus yang sering dijadikan pertimbangan oleh investor dalam pengambilan keputusan invetasi. Emiten yang menggunakan auditor bereputasi tinggi dapat memberikan sinyal positif kepada investor.

Dalam membuat keputusan untuk berinvestasi, investor akan mempertimbangkan salah satu informasi tentang financial leverage, dimana financial leverage menyajikan penilaian terhadap harga saham perdana, harga saham perdana yang terlalu tinggi menyebabkan terjadinya underpricing. Financial leverage sangat berpengaruh secara signifikan terhadap underpricing dengan tingkat signifikasi 10\% (Ghozali dan Mansur, 2002). Semakin besar tingkat kepemilikan yang ditahan (atau semakin kecil presentase saham yang ditawarkan) dapat memperkecil tingkat ketidakpastian pada masa yang akan datang.

$$
\text { Selain beberapa faktor }
$$

underpricing diatas ada satu faktor yang 
dapat mempengaruhi underpridicng yaitu ROA. ROA merupakan salah satu rasio kevangan yang dapat digunakan oleh pemegang saham dalam mengukur profitabilitas perusahaan secara keseluruhan. ROA menggambarkan kemampuan perusahaan mendapatkan laba denagn asset yang dimilikinya (Kasmir, 2010)

Berdasarakan latar belakang yang telah dikemukakan diatas, maka peneliti tertarik untuk melakukan kajian dengan beberapa faktor (reputasi underwriter,reputasi auditor, financial leverage, ROA) yang mempengaruhi underpricing dengan judul, "Pengaruh Variabel Keuangan Dan Non Keuangan Terhadap Underpricing Saham Pada Perusahaan Jasa Saat Initial Public Offering (IPO) Di Bursa Efek Indonesia (BEI) (Studi Kasus Pada Saham Syariah Dan Non Syariah) Periode 2012-2017."

\section{LANDASARAN TEORI}

\section{Underpricing}

Pengertian Underpricing Ketika perusahaan pertama kali melakukan penawaran sahamnya ke pasar modal, masalah yang dihadapi adalah penentuan harga di pasar perdana tersebut. Di satu pihak pemegang saham lama tidak ingin menawarkan saham baru dengan harga yang terlalu murah kepada investor baru, tetapi disisi lain investor menginginkan untuk memperoleh capital gains dari pembelian saham di pasar perdana tersebut (Allen and Faulhaber, 1989). Menurut Yolana dan Martani (2005) menjelaskan bahwa underpricing adalah adanya selisih positif antara harga saham di pasar sekunder dengan harga saham di pasar perdana atau saat IPO. Underpricing disebabkan oleh perbedaan kepentingan dari pihakpihak yang terkait dalam penawaran saham perdana. Harga saham yang dijual di pasar perdana ditentukan berdasarkan kesepakatan antara penjamin emisi (underwriter) dan emiten (issuers), sedangkan harga di pasar sekunder ditentukan oleh mekanisme permintaan dan penawaran.

Underpricing terbentuk atas suatu kondisi dimana secara rata-rata harga saham perusahaan yang baru go public, biasanya harga pada penawaran perdana lebih rendah daripada harga saham di pasar sekunder. Underpriced yang tinggi, akan merugikan jika dilihat dari sisi emiten karena perusahaan tidak dapat memperoleh dana secara maksimal. Hal ini disebabkan karena underwiter mengurangi tingkat risiko yang harus ditanggungnya karena fungsi penjaminannya. Sehingga perusahaan dinilai lebih rendah dari kondisi yang sebenarnya. Dalam mengembangkan pasar modal yang baik dan jika tidak ada pembatasan pada berapa banyak harga diperbolehkan untuk berfluktuasi oleh dari hari ke hari, tingkat penuh underpricing cukup jelas, tentunya dengan akhir hari pertama perdagangan, dan sebagainya kebanyakan studi menggunakan hari pertama harga penutupan saat menghitung kembali underpricing awal. Menggunakan harga kemudian, 
mengatakan pada akhir minggu pertama perdagangan, biasanya membuat sedikit perbedaan.

\section{Go Public}

\section{Pengertian Go Public}

Pengertian go public dalam konteks pasar modal adalah istilah yang ditujukan pada perusahaan yang menjual sebagian sahamnya ke masyarakat dan mencatat sahamnya di bursa efek. Go public juga biasa disebut sebagai penawaran umum perdana atau Initial Public Offering (IPO). Penawaran Perdana Saham atau Initial Public Offering (IPO) merupakan suatu mekanisme di mana perusahaan untuk pertama kalinya mengelvarkan saham baru yang kemudian ditawarkan kepada publik Fakhruddin (2008:76).

\section{Proses Go Public}

Pihak intern perusahaan atau calon emiten sebelum emisi di pasar perdana perlu melaksanakan Rapat Umum Pemegang Saham (RUPS) untuk menyetujui rencana go public yang diajukan manajemen perusahaan. Perusahaan lalu menunjuk profesi dan lembaga penunjang untuk membantu menyiapkan kelengkapan dokumen emisi yang digunakan untuk menyampaikan pendaftaran kepada BAPEPAM-LK. Bursa Efek sebelumnya memberikan persetujuannya melalui Kontrak Pendahuluan. BAPEPAM-LK kemudian memproses dokumen calon emiten untuk melakukan IPO, mulai dari tahap dokumen Pernyataan Pendaftaran yang diajukan emiten hingga akhirnya
BAPEPAM-LK memberikan Pernyataan Efektif.

Emiten yang mendapatkan Pernyataan Efektif telah bisa melakukan initial public offering (IPO) atau penawaran umum perdana. Tahapan ini merupakan tahapan utama, karena pada waktu inilah emiten menawarkan saham kepada investor di pasar perdana. Penawaran umum ini dilakukan oleh penjamin emisi (underwriter) dan agen penjualan. Underwriter bersama emiten pada tahapan ini melakukan penjatahan hingga distribusi efek kepada investor secara elektronik.

Emiten yang telah memperoleh dana melalui penawaran umum di pasar perdana, kemudian mencatatkan sahamnya di Bursa Efek. Perdagangan antar investor di pasar sekunder terjadi di tahapan ini, dimana harga saham akan bergantung pada mekanisme pasar atau pada hukum penawaran dan permintaan. Perusahaan publik selanjutnya sebagai bentuk tanggung jawabnya kepada investor harus melakukan keterbukaan informasi melalui penerbitan laporan berkala atau laporan kejadian penting lainnya.

\section{Reputasi Underwriter}

Fungsi penjamin emisi (underwriter) di dalam proses go public berdasarkan UU No. 8 tahun 1995 adalah menjadi pihak yang membuat kontrak dengan emiten untuk melakukan penawaran umum bagi kepentingan emiten dengan atau tanpa kewajiban untuk membeli sisa efek yang tidak terjual, oleh karena itu underwriter 
merupakan lembaga penunjang yang berperan besar bagi kelangsungan go public emiten. Hal ini dikarenakan selain menjadi lembaga yang membantu emiten dalam penyiapan semua dokumen yang diperlukan dalam seluruh proses go public, underwriter juga turut berupaya agar pemasaran penawaran umum perdana oleh emiten berjalan dengan sukses.

Reputasi underwriter telah banyak digunakan sebagai variabel independen yang menjelaskan penyebab underpricing pada IPO. Kiymaz (2000) menyatakan setidaknya terdapat tiga macam pengukuran reputasi underwriter dalam banyak literatur, yaitu teknik yang digunakan Carter dan Manaster (1990), Johnson dan Miller (1988), dan teknik yang digunakan oleh Megginson dan Weiss (1991). Teknik pemeringkatan reputasi underwriter pada penelitian ini menggunakan teknik Megginson dan Weiss. Megginson dan Weiss mengukur reputasi suatu underwriter dengan menggunakan rasio penjumlahan total dollar atau total nilai penawaran saham yang dikeluarkan ke pasar melalui semua IPO yang dilakukan oleh underwriter tersebut, dibagi dengan keseluruhan total dollar yang dikeluarkan atau total nilai penawaran saham dari seluruh IPO dalam sampel. Total nilai penawaran saham pada IPO yang memiliki lebih dari satu underwriter akan dibagi sama rata untuk menghitung market share dari setiap underwriter dalam IPO tersebut. Hal ini dikarenakan informasi mengenai proporsi untuk setiap underwriter dalam suatu IPO tidak tersedia.

\section{Reputasi Auditor}

Auditor mempunyai tugas utama untuk melaksanakan audit atas laporan keuangan perusahaan menurut standar audit yang ditetapkan Ikatan Akuntan Indonesia. Berdasarkan Keputusan Menteri Keuangan RI No.859/KMK.01/1987, salah satu persyataran dalam proses go public adalah laporan keuangan yang telah diaudit oleh kantor akuntan publik. Perusahaan yang akan go public harus memenuhi persyaratan bahwa laporan keuangan dua tahun terakhir adalah unqualified opinion.

Audit tersebut diperlukan agar publik memperoleh suatu keyakinan bahwa laporan keuangan tersebut bebas dari salah saji yang material, sehingga hal ini dapat dijadikan sebagai informasi yang diperlukan dalam rangka pengambilan keputusan oleh calon investor. Penelitian ini menentukan reputasi auditor dengan mengkategorikan pemeringkatan auditor sesuai dengan frekuensi auditor dalam melakukan audit pada perusahaan yang IPO. Sampel penelitian membagi nilai menjadi 6 kategori. Nilai 6 diberikan untuk auditor yang mengaudit klien paling banyak, sedangkan nilai 1 diberikan untuk auditor yang mengaudit klien paling sedikit.

\section{Financial Leverage}

Financial leverage menunjukkan kemampuan perusahaan dalam membayar hutangnya dengan equity yang dimilikinya. Apabila financial 
leverage tinggi, hal ini menunjukkan risiko suatu perusahaan tinggi pula. Sehingga, para investor dalam melakukan keputusan investasi, tentu akan mempertimbangkan informasi financial leverage (Daljono, 2000). Dengan demikian, untuk menghindarkan penilaian harga saham perdana terlalu tinggi yang menyebabkan terjadinya underpricing.

\section{Return on assets (ROA)}

Return on assets (ROA) merupakan suatu rasio penting yang dapat dipergunakan untuk mengukur kemampuan perusahaan dengan investasi yang telah ditanamkan (asset yang dimilikinya) untuk mendapatkan laba. ROA menjadi salah satu pertimbangan investor di dalam melakukan investasi terhadap sahamsaham di lantai bursa (Ghozali dan Mansur, 2002). Selain itu ROA merupakan ukuran profitabilitas perusahaan. Profotablitas perusahaan memberikan informasi kepada pihak luar mengenai efektifitas operasional perusahaan. Profitabilitas yang tinggi menunjukkan kemampuan perusahaan menghasilkan laba di masa yang akan datang dan laba merupakan informasi yang pentig bag investor sebagai pertimbangan untuk menanamkan modalnya (Misnen, 2004).

Hipotesis

Hipotesis dapat ditarik bedasarakan rumusan masalah, tujuan penelitian, dan landasan teori yang telah di paparkan sebelumnya. Hipotesis dari penelitian terdahulu ini adalah sebagai berikut:
$H_{1}$ : Reputasi underwriter berpengaruh terhadap underpricing saham perusahaan jasa saat IPO.

$\mathrm{H}_{2}$ : Reputasi auditor berpengaruh terhadap underpricing saham perusahaan jasa saat IPO.

$H_{3}$ : Financial Leverage berpengaruh terhadap underpricing saham perusahaan jasa saat IPO.

$H_{4}$ : ROA (Return on assets) berpengaruh terhadap besarnya tingkat underpricing saham perusahaan jasa saat IPO.

\section{METODE PENELITIAN}

\section{Pendekatan Penelitian}

Penelitian ini menggunakan pendekatan kuantitatif yang bertujuan untuk mengidentifikasi hubungan antar variabel dan pengujian hipotesis dengan menggunakan alat analisis statistik (Sugiyono, 2014). Pendekatan penelitian adalah analisis regresi linier berganda.

\section{Variabel Dependen}

Variabel dependen dalam penelitian ini adalah tingkat kolektabilitas pembiayaan. Variabel dependen dalam penelitian yaitu underpricing yang terjadi saat IPO di BEl.

\section{Variabel Independen}

1. Reputasi Underwriter

Penelitian ini menggunakan kategori (dummy). Apabila perusahaan jasa tersebut masuk dalam peringkat 50 penjamin emisi yang teraktif.

2. Reputasi Auditor

Semakin baik sebuah reputasi auditor maka akan semakin baik pula kualitas audit yang diperoleh. Variabel ini menggunakan kategori (dummy), 
KAP (auditor) yang bereputasi adalah KAP yang bermitra dengan the big four KAP dunia.

3. Financial Leverage

Financial leverage merupakan penggunaan dana yang menyebabkan perusahaan menanggung beban tetap berupa bunga dan diharapkan penghasilan akan lebih besar disbanding biaya bunga. Formula Financial Leverage dapat dirumuskan:

$F L=\frac{\text { Total Hutang }}{\text { Total Modal Sendiri }}$

4. Return on Assets (ROA)

ROA merupakan salah satu rasio keuangan yang dapat dugunakan oleh pemegang saham dalam mengukur profitabilitas perusahaan secara keseluruhan. Formula return on assets dapat dirumuskan:

ROA $=\frac{\text { Profit After } \operatorname{Tax}}{\text { Total Asset }} \times 100 \%$

\section{Jenis dan Sumber Data}

Jenis data dalam penelitian ini menggunakan data sekunder dengan mengumpulkan data.

\section{Populasi dan Sampel}

Populasi dalam penelitian ini yaitu perusahaan yang melakukan IPO yang sudah terctat di BEl pada periode 20122017. Metode pemilihan sampel yang gunakan dalam penelitian ini adalah purposive sampling.

\section{Teknik Analisis}

Teknik analisis dalam penelitian ini menggunakan analisis regresi linier berganda. Dimana untuk mengetahui apakah ada pengaruh yang signifikan dari beberpa variabel independen terhadap variabel dependen. Maka model regresi linier berganda yang dirumuskan sebagai berikut:

$$
Y=a+b_{1} x_{1}+b_{2} x_{2}+b_{3} x_{3}+b_{4} x_{4}
$$

\section{HASIL DAN PEMBAHASAN}

Bagian ini menjelaskan hasil analisis model dan pengujian hipotesis dari regresi linier berganda. Hasil analisis ini menggunakan dua regresi linier berganda maka diperoleh hasil persamaan sebagai berikut:

Tabel 2.

Hasil Estimasi Variabel yang Mempengaruhi Underpricing saat IPO di BEl Periode 2012-2017 (Saham Syariah)

\begin{tabular}{|c|c|c|c|c|c|}
\hline \multirow{2}{*}{ Model } & \multicolumn{2}{|c|}{ Unstandardized Coefficients } & \multirow{2}{*}{$\begin{array}{l}\text { Standardized Coefficients } \\
\text { Beta }\end{array}$} & \multirow{2}{*}{$\dagger$} & \multirow{2}{*}{ sig } \\
\hline & B & Std. Error & & & \\
\hline (Constant) & 22.828 & 4.086 & & 5.587 & .000 \\
\hline Underwriter & -18.927 & 8.725 & .496 & 2.169 & $.047^{*}$ \\
\hline Auditor & -20.381 & 7.205 & -.513 & -2.829 & $.013^{*}$ \\
\hline FinancialLeverage & -.703 & 1.738 & -.202 & -.405 & .691 \\
\hline $\mathrm{ROA}$ & -.616 & .542 & -.607 & -1.349 & .273 \\
\hline
\end{tabular}

Dependent Variable: Underpricing

*Signifikan pada a $5 \%$

Sumber: Data diolah

Dari tabel 2 Diperoleh persamaan sebagai

Underpricing $=22.828-18.927$ (Underwriter) berikut:

$$
\text { - 20,381(Auditor) - 0,703 }
$$




$$
\begin{aligned}
& \text { (Financial Leverage) - } \\
& 0.616(\mathrm{ROA})
\end{aligned}
$$

Artinya Dependent Variable: Underpricing

1. Nilai koefisien regresi reputasi underwriter diperoleh sebesar -18.927 hal ini menunjukkan bahwa perusahaan yang menggunakan underwriter yang bereputasi tinggi cenderung tingkat underpricing yang terjadi pada perusahaan tersebut akan lebih rendah sebesar 18.927 dibandingkan dengan perusahaaan yang menggunakan undewriter yang tidak memiliki reputasi tinggi.

2. Nilai koefisien regresi reputasi auditor diperoleh sebesar -20.381. Hasil ini menunjukkan apabila reputasi auditor yang digunakan bereputasi baik, maka nilai underpricing akan turun sebesar 20.381. hasil menunjukkan bahwa KAP big four akan menurunkan tingkat underpricing.
3. Jika variabel independen lainnya tetap dan financial leverage mengalami kenaikan $1 \%$ maka tingkat underpricing akan mengaalmi penurunan sebesar 70,3\%. Koefisien ini bernilai negatif artinya terjadi hubungan negatif antara financial leverage terhadap tingkat underpricing, semakin naik financial leverage maka semakin turun tingkat underpricing yang terjadi pada saat IPO.

4. Jika variabel independen lainnya tetap dan Return on assets (ROA) mengalami kenaikan $1 \%$, maka tingkat underpricing akan mengalami penurunan sebesar $61,6 \%$. Koefisien ini bernilai negatif artinya terjadi hubungan negative antara return on assets terhadap tingkat underpricing, semakin naik return on assets maka semakin turun tingkat underpricing yang terjadi pasa saat IPO.

Tabel 3.

Hasil Estimasi Variabel yang Memperngaruhi Underpricing saat IPO di BEl Periode 2012-2017 (Saham Non Syariah)

\begin{tabular}{llllll}
\hline \multirow{2}{*}{ Model } & \multicolumn{4}{l}{ Unstandardized Coefficients } & \multicolumn{2}{l}{ Standardized Coefficients } & & \multirow{2}{*}{ sig } \\
\cline { 2 - 5 } & $\mathrm{B}$ & Std. Error & Beta & & \\
\hline (Constant) & 27.966 & 11.354 & & 2.463 & .027 \\
\hline Underwriter & -28.739 & 10.221 & -.601 & -2.812 & $.014^{*}$ \\
\hline Auditor & -36.881 & 12.505 & -.651 & -2.949 & $.011^{*}$ \\
\hline FinancialLeverage & 3.136 & 2.784 & .275 & 1.126 & .279 \\
\hline ROA & .515 & 2.169 & .052 & .237 & .816 \\
\hline
\end{tabular}

Dependent Variable: Underpricing

*Signifikan pada a $5 \%$

Sumber: Data diolah

Dari tabel 3 Diperoleh persamaan sebagai berikut:

Underpricing $=27.966-28,739$ (Underwriter)

$$
\begin{aligned}
& -36.881 \text { (Auditor) + 3,136 } \\
& \text { (Financial Leverage) + } \\
& 0,515(\mathrm{ROA})
\end{aligned}
$$

Artinya:

1. Nilai koefisien regresi reputasi underwriter diperoleh sebesar -28.739 hal ini menunjukkan bahwa perusahaan yang menggunakan underwriter yang bereputasi tinggi cenderung tingkat underpricing yang terjadi pada perusahaan tersebut akan lebih rendah sebesar 28.739 
Setya, et al/Jurnal Ekonomi Syariah Teori dan Terapan Vol. 7 No. 5 Mei 2020: 886-900

dibandingkan dengan perushaaan yang menggunakan undewriter yang tidak memiliki reputasi tinggi.

2. Nilai koefisien regresi reputasi auditor diperoleh sebesar -36.881. hasil ini menunjukkan apabila reputasi auditor yang digunakan bereputasi baik, maka nilai underpricing akan turun sebsar 36.881. hasil menunjukkan bahwa KAP big four akan menurunkan tingkat underpricing.

3. Jika variabel independen lainnya tetap dan financial leverage mengalami kenaikan $1 \%$ maka tingkat underpricing akan mengalami peningkatan sebesar $313,6 \%$. Koefisien ini bernilai positif artinya terjadi hubungan positif antara financial leverage terhadap tingkat underpricing, semakin naik financial leverage maka semakin naik tingkat underpricing yang terjadi pada saat IPO.

4. Jika variabel independen lainnya tetap dan Return on assets (ROA) mengalami kenaikan $1 \%$, maka tingkat underpricing akan mengalami penurunan sebesar $51,5 \%$. Koefisien ini bernilai positif artinya terjadi hubungan positif antara return on assets terhadap tingkat underpricing, semakin naik return on assets maka semakin naik tingkat underpricing yang terjadi pada saat IPO.

Pengaruh Reputasi Underwriter Terhadap Underpricing saat IPO

Hasil perhitungan statistic
menunjukkan bahwa bahwa variabel reputasi underwriter secara parsial berpengaruh positif pada saham syariah dan berpengaruh negative pada saham non syariah dan signifikan terhadap underpricing dengan nilai signifikan 0,047 pada saham syariah, 0,014 pada saham non syariah. Hal ini mendukung hasil penelitian sebelumnya yang dilakukan oleh Daljono (2000), Beatty \& Ritter (1986), Carter \& Manaster, (1990), Kristiantari (2013).

Alasan yang mendasari hasil penelitian ini adalah underwriter yang memiliki reputasi akan lebih berani menghadapi risiko dengan menetapkan harga saham IPO yang relative tinggi karena konsekuensi kualitas penjamin yang dimilikinya. Dengan demikian, reputasi penjamin emisi dapat dipakai sebagai sinyal untuk mengurangi ketidakpastian yang tidak dapat diungkapkan oleh informasi yang terdapat dalam prospectus dan memberi sinyal bahwa informasi privat dari emiten mengenai prospek perusahaan di masa akan datang.

\section{Pengaruh Reputasi Auditor Terhadap Underpricing saat IPO}

Hasil perhitungan statistik menunjukkan bahwa variabel reputasi auditor secara parsial memiliki pengaruh negatif dan signifikan terhadap underpricing dengan nilai signifikan 0,013 pada saham syariah, 0,011 pada saham non syariah. Nilai koefisien yang negatif menunjukkan semakin tinggi reputasi auditor maka tingkat underpricing pada IPO akan semakin rendah. Hal ini 
mendukung hasil penelitin sebelumnya yang dilakukan oleh Hapsari (2012), Lestari et al. (2015).

Hasil penelitian ini berarti bahwa reputasi auditor mempengaruhi tinggirendahnya tingkat underpricing di pasar perdana. Berkaitan dengan penjelasan pada hasil hipotesis pertama sebelumnya, yaitu kemungkinan tingkat underpricing lebih dipengaruhi oleh variabel-variabel keuangan lainnya. Auditor adalah pihak yang menilai layak tidaknya suatu laporan keuangan yang diterbitkan oleh perusahaan. Auditor memiliki peranan yang penting dalam membuat publik yakin bahwa laporan keuangan tersebut bebas dari salah saji yang material. Perusahaan dengan auditor bereputasi baik dapat membuat publik merasa yakin atas kebenaran laporan kevangan perusahaan, sehingga informasi akuntansi yang dibutuhkan publik untuk menilai perusahaan dinilai lebih terpercaya, maka tingkat underpricing dapat lebih diminimalisir.

\section{Pengaruh Financial leverage Terhadap Underpricing saat IPO}

Hasil perhitungan statsitik menunjukkan bahwa variabel financial leverage tidak berpengaruh secara signifikan terhadap underpricing dengan nilai signifikan 0,691 pada saham syariah 0,279 pada saham non syariah dimana nilai signifikan lebih besar dari 0,05. Temuan ini tidak didukung oleh hasil penelitian yang dilakukan Daljono (2000), yang menyatakan adanya hubungan siignifikan antara financial leverage terhadap underpricing. Namun temuan ini mendukung hasil penelitian yang dilakukan oleh durukan (2002) yangmenyatakn bahwa financial leverage tidak berpengaruh secara signifikan terhadap underpricing.

\section{Variabel financial leverage} menunjukkan tidak berpengaruh signifikan terhadap tingkat underpricing. Alasan mengapa financial leverage tidak berpengaruh terhadap underpricing adalah karena rasio yang menunjukkan rasio hutang ini lebih mencerminkan resiko perusahaan yang relatif tinggi sehingga megakibatkan ketidakpastian harga saham dan berdampak pada return saham yang nantinya akan diterima investor, akibatnya investor cenderung menghindari saham-saham yang memiliki financial leverage tinggi.

\section{Pengaruh Return on assets (ROA) Terhadap Underpricing IPO}

Hasil perhitungan statistik menunjukkan bahwa variabel return on assets (ROA) tidak berpengaruh secara signifikan terhadap underpricing dengan nilai signifikan 0,273 pada saham syariah, 0,816 pada saham non syariah dimana nilai signifikan lebih besar dari 0,05 . Hal ini dapat diartikan bahwa besar kecilnya ROA tidak akan mempengaruhi underpricing pada perusahaan yang melakukakn IPO. Hal ini mendukung hasil penelitian sebelumnya yang dilakukan oleh Kristiantari (2013), Y. O. Lestari (2011).

Tidak berpengaruhnya ROA pada underpricing dapat diakibatkan oleh ketidakpercayaan investor atas informasi 
keuangan yang disajikan oleh emiten selain itu pera investor tidak hanya memperhatikan ROA dalam prospectus, tetapi mungkin investor juga memperhatikan ROA untuk beberapa tahun sebelum perusahaan mewakukan IPO. Dengan demikian investor mengetahui apakah laporan kevangan tersebut di mark-up atau tidak.

\section{SIMPULAN}

Penelitian ini meneliti tentang faktor-faktor yang mempengaruhi Underpricing pada saat terjadi IPO tahun 2012-2017 pada perusahaan jasa yang terdaftar di BEl. Anaisis dilakukan dengan menggunakan analisis regresi berganda dengan program Statistical Package for Social Science (SPSS) versi 16. Data sampel perusahaan terbagi menjai dua yaitu perusahaan jasa saham syariah sebanyak 20 dan perusahaan jasa saham non syariah sebanyak 19 selama periode 2012-2017.

Hasil pegujian dan pembahasan pada bagian sebelumnya menjelaskan bahwa Variabel yang dapat mempengaruhi underpricing saat IPO terjadi periode 2012-2017 hanya dua variabel yang memepengaruhi yaitu variabel reputasi underwriter dan variabel reputasi auditor hal ini terjadi pada saham syariah dan saham non syariah di perushaan jasa. Sedangkan dua variabel lagi yaitu financial leverage dan return on assets tidak berpengaruh terhadap underpricing pada saat IPO, hal ini terjadi pada kedua jenis saham yaitu saham syariah dan saham non syariah di perusahaan jasa.

\section{Saran}

Berdasarkan hasil penelitian ini, saran yang bisa diberikan sebagai berikut:

1. Bagi emiten yang akan melakukan IPO hendaknya memilih auditor yang berupasi baik guna untuk meminimalisir terjadinya underpricing. Selain itu emiten juga harus memilih jasa underwriter yang beruputasi baik, dimana hal agar tercipta harga yang saling menguntungkan satu sama lain serta jika terjadi underpricing, maka tidak akan tercipta underpricing yang terlalu tinggi.

2. Bagi para investor yang ingin menanamkan modalnya pada saat IPO, dengan beracuan pada hasil penelitian ini diharapkan para investor dapat melihat informasi reputasi auditor. Hal tersebut dikarenakan hasil penelitian ini menunjukkan bahwa reputasi auditor berpengaruh secara siginifikan pada saham syariah maupun non syariah. Reputasi auditor yang bereputasi baik dalam hal ini Kap big four yang menghasilkan kualitas audit yang independen dan terbebas dari salah saji material. Setidaknya auditor diharapkan dapat memberikan hasil audit yang independen sehingga menjadi acuan bagi investor untuk berinvestasi di perusahaan yang melakukan IPO. Oleh karena itu reputasi auditor dapat menghilangkan keraguan 
investor untuk menanamkan modalnya pada saham IPO.

\section{DAFTAR PUSTAKA}

Anwar, Y. (2010). Pasar modal sebagai sarana pembiayaan dan investasi. Bandung: Alumni.

Beatty, R. P., \& Ritter, J. R. (1986). Investment banking, reputation, and the underpricing of initial public offerings. Financial Economics, 15(1), 213-232.

Carter, R., \& Manaster, S. (1990). American finance association initial public offerings and underwriter reputation author (s): Richard Carter and Steven Manaster. The Journal of Finance, 45(4). 10451067.

Chastina, Y., \& Martani, D. (2005). Variabel-variabel Memperngaruhi Underpricing pada penawaran saham perdana di BEJ Tahun 1994-2001. SNA, 8.

Daljono. (2000). Analisis faktor-faktor yang mempengaruho initial return saham yang listing di BEJ tahun 1990-1997. SNA, 3.

Fahmi, I. (2012). Pengantar pasar modal panduan bagi para akademis dan praktisi bsinis dalam memahami pasar modal Indonesia. Bandung: Alfabeta CV.

Ghozali, I., \& Mansur, M. al. (2002). Analisis faktor-faktor yang mempengaruhi tingkat underpricing di bursa efek Indonesia. Bisnis dan Akuntansi, $4(1)$.

Handayani, S. R. (2008). Analisis faktorfaktor yang mempengaruhi underpricing saham pada penawaran umum perdana (Studi kasus pada perusahaan keuangan yang Go Public di Bursa Efek Jakarta Tahun 2000-2006). Skripsi tidak diterbitkan. Semarang: Universitas Diponegoro.

Hapsari, V. A. (2012). Analisis faktor-faktor yang mempengaruhi underpricing saham pada penawaran umum perdana di BEl Periode 20082010. Diponegoro Journal of Management, 1 (1), 1-9.

Jannah, K. M. (2016). Peluang investasi di pasar modal syariah.

Kadek, P., Raditya, A., \& Yasa, G. W.
(2017). Reputasi auditor sebagai pemoderasi pengaruh informasi keuangan dalam prospektus pada tingkat underpricing penawaran saham perdana. E-Jurnal Akuntansi, 21 (3), 1963-1992.

Kasmir. (2010). Pengantar manajemen keuangan. Jakarta: Kencana Prenada Media Group.

Khan, T., \& Ahmed, H. (2008). Manajemen risiko: Lembaga keuangan syariah. Jakarta: PT Bumi Aksara.

Kristiantari, I. D. (2013). Analisis faktorfaktor yang mempengaruhi underpricing saham pada penawaran saham perdana di Bursa Efek Indonesia. Ilmiah Akuntansi Dan Humanika, 2 (2), 785811.

Lestari, A. H., Hidayat, R. H., \& Sulasmiyati, S. (2015). Analisis faktor-faktor yang mempengaruhi underpricing saham pada penawaran umun perdana di BEl periode 2012-2014 (Studi pada perusahaan yang Melaksanakan IPO di Bursa Efek Indonesia periode 2012-2014). Administrasi Bisnis, 25(1), 1-9.

Lestari, Y. O. (2011). Pengaruh informasi keuangan dan non keuangan terhadap return saham di pasar perdana. Akuntansi Aktual, 1(1), 110.

Muhamad, S. (2006). Pasar modal dan manajemen portofolio. Surabaya: Erlangga.

Nugroho, R., \& Nanda, R. (2016). Analisis investasi atau penanaman modal dalam konsep ekonomi Islam. Universitas Islam Indonesia Yogyakarta.

Retnowati, E. (2013). Penyebab underpricing pada penawaran saham perdana di Indonesia. Accounting Anlysis Journal, 1(4), 173-192.

Safithri, M., Setyaningsih, I., Tarman, K., Suptijah, P., \& Yuhendri, V. M. (2018). Potensi kolagen teripang emas sebagai inhibitor tirosinase. JPHPI, 21 (2), 295-303.

Siamat, D. (2005). Manajemen lembaga keuangan, kebijakan moneter dan perbankan. edisi pertama. Jakarta: Fakultas Ekonomi Universittas Indonesia. 
Setya, et al/Jurnal Ekonomi Syariah Teori dan Terapan Vol. 7 No. 5 Mei 2020: 886-900

Sugiyono. (2014). Metode penelitian kuantitatif, kualitatif, dan R\&D. Bandung: Alfabeta CV.

Suyatmi, \& Sujadi. (2006). Faktor-faktor yang mempengaruhi underpricing pada penawaran umum perdana di Bursa Efek Jakarta. Jurnal Benefit, 10(1), 11-32. 